\title{
'n Preek vol aanhalings: \\ Miga 1 vanuit 'n redaksie-historiese perspektief
}

\author{
JG Strydom \\ Universiteit van Suid-Afrika
}

\begin{abstract}
A sermon full of quotations: Micah 1 from a redactionhistorical perspective
\end{abstract}

In his Micah commentary, published in 1976, AS van der Woude holds the view that Micah 1 has to be understood as a literary and historically-original unit, a sermon which Micah delivered at Lachish. In this article it is agreed that Micah 1, in its present form, indeed forms a literaty unit (a sermon), but against Van der Woude, the thesis is put forward that the sermon does not form a historically-original unit; it rather underwent a historical development in the sense that Micah, in delivering the sermon in $701 \mathrm{BC}$ (not 722/1 $B C$ as Van der Woude suggests), made use of (quotations from) two prophecies, spoken by himself, against Samaria (722/1 BC) and Jerusalem (714-711 BC). The present form of the chapter therefore has to be ascribed to Micah himself, and not to the redactor of the book.

Met sy Migakommentaar, wat in 1976 verskyn het, het AS van der Woude 'n interessante teorie oor die verstaan van Miga 1 op die tafel geplaas. In die verlede is hierdie hoofstuk oor die algemeen in noue samehang met die res van die boek geïnterpreteer, met ander woorde as inherente en onlosmaaklike deel van 'n groter literêre eenheid. Dit is veral binne die verband van Miga 1-3 gedoen, omdat laasgenoemde, volgens die meeste kommentatore, die enigste deel van die boek Miga is wat met sekerheid aan die profeet self toegeskryf kan word. Daarenteen beskou Van der Woude (1976: 19-22) hierdie hoofstuk (uitgesonderd Miga 1: 1 wat die opskrif van die hele boek is) as 'n selfstandige literêre eenheid wat uit die tyd 
net voor die val van Samaria dateer, meer spesifiek, as 'n preek wat Miga, tydens die Loofhuttefees, te Lagis gelewer het. Volgens Van der Woude het Miga waarskynlik juis hier in Lagis sy profetiese werksaamhede begin in ongeveer die jaar $723 \mathrm{vC}$.

Afgesien daarvan dat Van der Woude (1976: 19) meen dat Miga 1: 2-16 'n literêre eenheid vorm, beskou hy dit ook, in sy huidige vorm, as 'n historiese eenheid in dié sin dat die verskillende sub-eenhede van die hoofstuk (kyk hieronder) nooit onafhanklik van mekaar bestaan of gefunksioneer het nie; die hoofstuk is as geheel 'geskep' tydens die eerste lewering van die preek. Dat die preek wel te Lagis gelewer is kan, aldus Van der Woude, nie bewys word nie, maar is baie waarskynlik in die lig van die volgende klimaktiese opbou van die hoofstuk:

Verse 2-5 Miga begin sy prediking met 'n universele Godsgerig. Hy betrek dit dan egter op Jahwe se eie, van Hom vervreemde, volk, meer spesifiek onderskeidelik op die inwoners van

verse 6-7 Samaria

verse 8-12 Jerusalem

verse 13-16 en Lagis.

Gegewe dat die preek te Lagis gelewer is, bou Miga spanning op deur die kring al nouer te trek (Van der Woude 1976: 20). Eers wend hy hom tot die vreemde volke wat teoreties ver verwyderd is, dan tot die inwoners van die Noordrykse stad Samaria, wat ook geografies verwyderd is, maar darem al deel van die Godsvolk uitmaak. Hierna rig hy hom tot die inwoners van Jerusalem, wat net die spreekwoordelike hanetreetjie van Lagis af is, en dan direk tot die mense van Lagis wat fisies voor hom sit. Die klimaks van die hoofstuk moet ook teen die agtergrond van die voortgang en ontwikkeling van die hoofstuk gesien word: Die aanvanklike gerusstellende en tradisionele vorm van prediking (1: 2-4) verander skielik in 'n felle oordeelsaankondiging (1: 5-16).

Ek is dit eens met Van der Woude dat Miga 1: 2-16, in sy huidige vorm, 'n literêre eenheid uitmaak. Die struktuur wys duidelik dat die verskillende subgedeeltes onlosmaaklik aan mekaar verbind is. Verder maak die klimaktiese toespitsing op Lagis dit baie waarskynlik dat die preek wel in die heiligdom ter plaatse gelewer is. Myns insiens beteken dit egter nie noodwendig dat die preek, in sy huidige vorm, ook 'n historiese eenheid vorm in die sin dat die verskillende subgedeeltes nie op ' $n$ vroeër stadium onafhanklik van mekaar kon bestaan het nie. 
Inteendeel, ek meen dat 'n saak daarvoor uitgemaak kan word dat ons hier met 'n preek van Miga te doen het waarin hy gebruik gemaak het van reeds bestaande profesieë wat hyself by vorige geleenthede uitgespreek het. Met ander woorde, alhoewel die hoofstuk tans 'n literêre eenheid vorm, het dit 'n bepaalde historiese ontwikkeling deurloop. Wat duidelik gesê moet word, is dat hierdie saamgestelde karakter van hoofstuk 1 nie, soos sommige kommentatore beweer, die werk van die finale redaktor van die boek is nie, maar wel van Miga self.

\section{MIGA 1: 2-16 IN SY HUIDIGE VORM}

Soos reeds genoem, sê Van der Woude dat die hoofstuk literêr en histories 'n eenheid vorm. Ons begin ons bespreking by die stelling dat dit 'n literêre eenheid is. Hierdie deel van Van der Woude se tese word deur 'n formele sowel as 'n inhoudelike analise bevestig. Kom ons kyk eers kortliks na die afsonderlike sub-eenhede en dan na die struktuur van die hoofstuk as geheel (vir 'n vollediger bespreking hiervan, kyk Strydom 1988: 166-186).

\subsection{Miga 1: 2-5}

2. Luister, alle volke; let op, aarde en sy volheid, want Jahwe, die Here, sal as regter teen julle optree, die Here vanuit sy heilige tempel.

3. Ja kyk, Jahwe is op die punt om uit sy woning uit te gaan. Hy daal af en betree die hoogtes van die aarde.

4. En die berge smelt onder Hom en die waterdieptes skeur oop, soos was voor vuur, soos water wat teen ' $n$ helling afloop.

5. Vanweë die ontrou van Jakob (gebeur) dit alles, vanweë die sondes van die huis van Israel. Wie is die ontrou (naamlik) Jakob? Is dit nie Samaria nie? En wie is die Judahoogtes? Is dit nie Jerusalem nie?

Ons het hier te doen met 'n oproep aan die volke om te luister, omdat Jahwe sy oordeel gaan voltrek (1:2), gevolg deur 'n beskrywing van die epifanie van Jahwe (1: 3-4). Wat egter belangrik is ten opsigte van die verstaan van die hoofstuk as geheel, is dat in vers 5 , téén die verwagting in, vermeld word dat Jahwe nie oor die sonde van die ander volke sy gerig kom voltrek nie, maar wel oor dié van sy eie volk.

Ons het dus hier die situasie dat Miga doelbewus by die genre van die profesieë teen die vreemde volke aansluit (Van der Woude 1976: 24). Op die manier bou hy 'n verrassingselement in sy prediking in: Hy rig hom aanvanklik, op eg tradisionele wyse, tot die ander volke, sodat die mense voor hom moet dink dat die oordeel van 
God dié mense gaan tref. As hy hom dan in vers 5 skielik tot hulle rig, tref dit soveel harder.

\section{Miga 1:6-7}

Nadat Miga die rede vir God se koms en oordeel in algemene terme gegee het (1: $5 a)$ en Samaria pertinent by die naam genoem het (1: $5 \mathrm{~b})$, kondig hy nou God se oordeel oor Samaria aan (1:6-7).

6. Daarom sal Ek Samaria tot 'n puinhoop maak, die oop veld tot 'n plek om wingerde te plant. Haar stene sal Ek in die dal laat afrol en Ek sal haar fondamente blootle.

7. En al haar gesnede beelde sal stukkend geslaan word en al haar wygeskenke sal met vuur verbrand word en al haar afgode sal Ek tot puin maak; want uit hoereloon het sy dit bymekaargemaak en tot hoereloon sal dit terugkeer.

Een interessante aspek kan hier uitgelig word. Van der Woude (1976: 36) sê dat die woorde van vers 7 , waarin op die uitwerking van Jahwe se ingrype gewys word, die hoogtepunt van die profesie teen Samaria vorm. Met sy oordeel sal Jahwe dit duidelik maak dat $\mathrm{Hy}$ alleen gedien moet word en dat alle heil van Hom alleen te wagte is. Na my mening is vers 6b egter die klimaks: Formeel is dit die enigste stige wat, naas die feit dat dit 'n inhoudelike parallelisme vorm, ook grammatikaal 'n chiasme vertoon:

werkwoord
Ek sal laat afrol
en haar fondamente
objek

werkwoord

objek

$$
\text { objek }
$$

haar stene

$$
\begin{gathered}
\text { sal Ek blootlê } \\
\text { werkwoord }
\end{gathered}
$$

Inhoudelik maak dit ook meer sin dat die kern van die oordeel oor Samaria juis behels dat die stad tot niet sal gaan (1: 6b), veral in die lig daarvan dat Miga hierdie woorde oorspronklik (kyk die bespreking hieronder) net voor die val van Samaria uitgespreek het.

\section{Miga 1: 8-12}

In hierdie verse rig Miga hom tot die stad wat hy reeds by name in vers $5 \mathrm{~b}$ genoem het, naamlik Jerusalem. 
8. Daaroor wil ek weeklaag en huil, kaalvoet en naak loop; ek wil weeklagte uitstort soos die jakkalse en roukrete soos die volstruise.

9. Waarlik, die ramp wat haar sal tref, sal ongeneeslik wees, want dit sal strek tot by Juda; dit sal reik tot by die poort van my volk, tot by Jerusalem.

10. Moenie dit in Gat vertel nie, moenie hardop huil nie; in Bet-Leafra rol hulle hulleself in die stof.

11. Die inwoners van Safir blaas vir julle op die krygsbasuin; die inwoners van Saänan trek nie die oop veld in nie; die geweeklaag van Bet-Haësel maak dat julle sy steun moet ontbeer.

12. Ja, die inwoners van Marot bewe vreeslik van angs, want onheil, van Jahwe af, daal af na die poort Jerusalem.

Van der Woude (1976: 37-42) sê dat al bestaan daar formele ooreenkomste tussen verse 8-12 en 13-16, het ons met twee afsonderlike sub-eenhede binne die geheel van hoofstuk 1 te doen. Dit blyk onder andere uit die volgende: In verse 8-12 word die toegesprokenes in die meervoud aangedui, in verse 13-16 in die enkelvoud; in verse 8-12 vertoon dié stiges wat woordspeling op 'n pleknaam bevat 'n $2+2$ metrum, terwyl die analoë stiges in verse 13-16 'n 3+2 metrum vertoon; alhoewel albei gedeeltes in die teken van nomen est omen staan (die woordspeling op die plekname bring die verborge samehang tussen die naam.van die plek en die lot wat hom sal tref, na vore), is dit so dat verse 10-12 oor die direkte omgewing van Jerusalem handel en verse 13-16 weer oor Suidwes-Juda; vers 12b het boonop 'n afsluitende karakter en sodoende word twee sub-eenhede gevorm wat elk uit nege stiges bestaan (vers 8 as inleiding uitgesluit) en wat woordspeling op vyf plekname bevat.

Alhoewel ek meen dat daar nie so 'n direkte verband tussen die metrum en die woordspeling bestaan as wat Van der Woude voorgee nie (vir ' $n$ volledige bespreking hiervan, kyk Strydom 1988: 176-178, 180-182), stem ek wel saam dat ons hier met twee afsonderlike sub-eenhede te doen het.

\subsection{Miga 1: 13-16}

Soos reeds gesê, vorm verse 13-16 die klimaks van Miga se prediking. Hier wend hy hom direk tot sy onmiddellike gehoor, naamlik die inwoners van Lagis.

13. Span die perde voor die strydwaens, inwoners van Lagis; jy is immers 'n bron van sonde vir die dogter Sion, want in jou word die ontrouhede van Israel gevind.

14. Daarom, gee 'n afskeidsgeskenk aan Moreset Gat. Die werkplekke van Agsib 
sal 'n teleurstelling vir die konings van Israel wees.

15. Opnuut sal ek vir jou 'n veroweraar bring, inwoners van Maresa. Na Adullam sal die heerlikheid van Israel afsak.

16. Maak 'n kaalte (op jou kop) en skeer jou vanweë jou troetelkinders. Maak jou kaalplek so groot soos die van 'n aasvoël, want hulle gaan in ballingskap van jou af weg.

Van der Woude (1976: 52-53) sê dat alhoewel verse 13-16 die metrum van 'n klaagsang vertoon, is dit nie 'n klaagsang nie. In vers $13 \mathrm{~b}$ het ons 'n Scheltwort, terwyl verse 14-15 sterk trekke van 'n Drohwort vertoon. Die tema van die verse is ook nie 'n klag nie, maar wel stryd, besetting en ballingskap.

Op grond hiervan kan gesê word dat ons in verse 13-16 na funksie, en grotendeels ook na vorm, met 'n spesifieke vorm van 'n onheilsprofesie te doen het.

Ten opsigte van hierdie verse moet kortliks aandag gegee word aan 'n aspek wat van belang is vir die interpretasie van die hoofstuk as geheel. 'n Aantal kommentatore, byvoorbeeld Jeremias (1971: 338), meen dat vers 13b sekondèr is: Daar word van die derde persoon aanspreekvorm gebruik gemaak, terwyl vers 13a in die tweede persoon is; vers $13 \mathrm{~b}$ pas nie in die konteks nie omdat dit tot Jerusalem gerig is en nie meer tot Lagis (1:13a) nie; die vers bevat nie, soos die omringende verse, 'n woordspel nie; dit is onwaarskynlik dat die oproep van vers 13 met 'n anklag gemotiveer sal word ('n mens sou eerder 'n onheilsaankondiging verwag); vers $13 \mathrm{~b}$ gee 'onnodiglik' 'n 'ekstra' rede vir die oordeel oor Lagis, omdat vers 5a, in terme van die hoofstuk as geheel, die rede vir die oordeel verskaf. Naas die argumente waarmee Van der Woude (1976: 53-55) hierdie opvatting, myns insiens, oortuigend weerlê, kan die volgende besware ook nog teen Jeremias se siening ingebring word: Die feit dat, naas die rede in vers $5 a$, 'n 'ekstra' rede vir die oordeel oor Lagis gegee word (anders as in die geval van Samaria en Jerusalem), rym daarmee dat die hele preek op Lagis toegespits is en Miga nou praat met die mense wat letterlik voor hom sit. Die feit dat vers 13 b nie woordpel bevat nie, beteken ook nie dat dit sekondèr is nie; vers 16 bevat ook geen woordspel nie.

\subsection{Die struktuur van Miga 1: 2-16}

\subsubsection{Verse 2-5}

Verse 2-4 vorm formeel 'n eenheid, soos bewys deur die 7 (1:3) en die 7 konsekutief (1:4) wat telkens 'n verband met die voorafgaande lè. Verse 3-4 vorm eintlik ' $n$ nog kleiner eenheid omdat die 7 op beide verse 3 en 4 van toepassing is en daar inhoudelik 'n eng verband tussen die twee verse bestaan. Ons het hier te 
doen met 'n oproep aan die volke om te luister, omdat Jahwe sy oordeel gaan voltrek (1: 2), gevolg deur 'n beskrywing van die epifanie van Jahwe (1:3-4).

Vers 5 sluit formeel by verse $2-4$ aan omdat die uitdrukking 'dit alles (gebeur)' (1:5a) na die voorafgaande verse verwys. Op sigself maak vers 5 ook ' $n$ eenheid in die kleine uit. Waar verse $2-4$ tot alle volke gerig is, is vers 5 tot die Godsvolk spesifiek gerig.

\subsubsection{Die funksie van vers 5}

Ten opsigte van vers 5 is dit nodig om te kyk na die besondere funksie wat hierdie vers binne die hoofstuk as geheel vervul. Van der Woude (1976: 31-33) meen dat die benamings 'Jakob' en 'die huis van Israel' (1:5a) parallel gebruik word en op die hele Godsvolk as 'n religieuse gemeenskap dui. So gesien, funksioneer vers $5 \mathrm{a}$ as 'n duidelike toespitsing - waar daar tot dusver met die volke in die algemeen gepraat is, word nou pertinent met die Godsvolk gepraat. Terselfdertyd dien vers 5a, met die beskuldiging wat daarin vervat is, ook as die motivering vir al drie die oordeelsuitsprake wat volg, naamlik die gerig oor Samaria (1: 6-7), dié oor Jerusalem (1: 812) en dié oor Lagis (1: 13-16). Op dié manier is vers 5a dus eintlik die skarnier waarom die hoofstuk as geheel draai. Dat Van der Woude hier gelyk het, sal ook uit die res van die bespreking blyk.

Ek stem egter nie saam met Van der Woude se siening dat verse $5 \mathrm{~b}$ en $5 \mathrm{c}$ 'n glos is wat op 'n later stadium deur die Deuteronomistiese uitgewer van die boek by vers 5a gevoeg is nie. Myns insiens is die argumente waarmee Van der Woude dit motiveer, nie deurslaggewend nie; dié verse kan wel aan Miga toegeskryf word (ek sal egter later volledig hieraan aandag gee). Wat meer is, of verse $5 b-c$ nou ' $n$ latere redaksionele toevoeging is of nie, verander as sodanig nie aan die feit dat dit binne die hoofstuk, soos dit tans daar uitsien, 'n belangrike funksie vervul nie.

In die eerste plek dien die twee stiges as 'n verdere toespitsing van vers $5 \mathrm{a}$ : In laasgenoemde is na die Godsvolk as geheel verwys, in verse $5 b$ en $5 c$ word dit op onderskeidelik Samaria en Jerusalem toegepas. In die tweede plek word met dié stiges voortgegryp op die oordeel wat in verse 6-7 en 8-12 oor onderskeidelik Samaria en Jerusalem uitgespreek word (vergelyk in dié verband 'Samaria' wat in verse $5 b$ en 6 voorkom, en 'Juda' en 'Jerusalem' wat in verse $5 c$ en 9 voorkom).

\subsubsection{Die verband tussen verse 6-7, 8-12 en 13-16}

Dat verse 8-12 op sigself ook voortbou op verse 6-7, blyk uit die 'daaroor' aan die begin van vers 8 en die opname van 'Samaria' (1:6) met die tweede persoon enkelvoud vroulik suffiks ('die ramp wat haar sal tref) in vers 9 .

Verse 13-16 bou ook spesifiek op verse 6-7 en 8-12 voort, soos aangedui deur 
die benamings 'Israel' en 'dogter Sion' (1: 13b-c) waarmee daar na die gedeeltes oor Samaria (1: 6-7) en Jerusalem (1: 8-12) verwys word.

\subsubsection{Verse 2-16 as geheel}
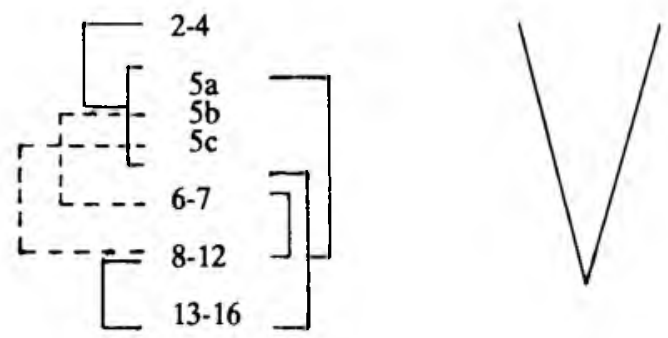

Uit al bogenoemde blyk dus dat die hele hoofstuk klimakties opgebou is en toespits op verse 13-16. Miga begin sy preek in algemene terme, dit lyk asof hy die ander volke aanspreek (1: 2-4). Die oomblik wat sy gehoor gerus raak, slaan hy toe en betrek Jahwe se oordeel op die Godsvolk as geheel (1: 5a). Direk daarna noem hy kortliks Samaria (1: 5 b) en Jerusalem (1: $5 c$ ) by die naam, en dan spits hy hom toe, eers op Samaria (1: 6-7) en dan op Jerusalem (1: 8-12). In die proses raak sy gehoor weer gerus; dit gaan oor ander stede. Tegelykertyd is daar egter ook in hierdie 'ander' stede 'n nouer trek van die kring: Eers Samaria, wat in die Noordryk lè, en dan Jerusalem wat al heelwat nader is. Uiteindelik slaan Miga dan toe op die inwoners van Lagis, die mense wat voor hom sit.

\section{DIE REDAKSIEGESKIEDENIS VAN MIGA 1: 2-16}

Dit bring ons by die tweede element van Van der Woude se tese, naamlik dat Miga 1: 2-16 ook histories 'n eenheid vorm. Omdat die gedeelte 'n literêre eenheid vorm, het die verskillende sub-eenhede daarvan (uitgesluit verse $5 \mathrm{~b}-\mathrm{c}$ wat 'n latere toevoeging is), volgens Van der Woude (1976: 41), in dieselfde tyd ontstaan. Op grond hiervan dateer hy die hoofstuk kort voor die val van Samaria (722/1 vC) omdat Samaria, volgens verse 6-7, sal val en nie reeds geval het nie.

In hierdie opsig verskil talle kommentatore van Van der Woude, veral wat betref sy indeling van die hoofstuk, die dele wat hy aan Miga self toeskryf en die vraag of die huidige vorm van die hoofstuk die werk van Miga of van die redaktor van die boek is. Enkele van die standpunte is die volgende:

- Mays (1976) sê dat verse 3-5a en 8-15 (uitgesonderd verse 12 en 13b) van Miga 
af kom, terwyl verse $2,5 b-c, 6-7,12 b, 13 b$ en 16 van die latere redaktor van die boek afkomstig is. Volgens hom wou die redaktor met vers 2 'n brug slaan tussen die opskrif van die boek (1:1) en die teofaniebeskrywing (1:3-4), terwyl verse 6-7 ingevoeg is na aanleiding van die opskrif van die boek waarin van Samaria sprake is. Verse $5 b$ en $5 c$ is weer bygevoeg om onderskeidelik verse 67 en 8-16 aan verse 2-5a te verbind. Verse $12 b, 13 b$ en 16 is ook bygevoeg as deel van die redaksionele proses waarvolgens Miga 1 tot 'n eenheid verwerk is.

- Allen (1976) sê dat ons met twee afsonderlike profesieë te doen het: Verse 2.9 wat 'n oordeelsaankondiging oor Samaria en Jerusalem uit die tyd net voor die val van Samaria is, en verse 10-16, 'n profesie oor Juda en Jerusalem, wat verband hou met Sargon se veldtog van 720 of 714-711 vC. Die twee profesieë is later, vanweë ' $n$ tematiese ooreenkoms, saamgevoeg om 'n eenheid te vorm.

- Rudolph (1975) sê dat verse 2-7 (vers 5c uitgesluit) uit die tyd voor $722 \mathrm{vC}$ kom terwyl verse 10-16 en verse 8-9 (wat as oorgang tussen 2-7 en 10-16 funksioneer) op die katastrofe van $701 \mathrm{vC}$ sinspeel. Omdat verse 8-16 dié katastrofe egter net voorspel, kon dit by 'n vroeër geleentheid uitgespreek gewees het. In die lig daarvan dat Gat (wat in vers 10 genoem word) ná $711 \mathrm{vC}$ nie meer deel van Juda was nie, moet dit voor dié tyd wees. Dit kan selfs voor $722 \mathrm{vC}$ wees wat sou beteken dat die hele gedeelte oorspronklik 'n eenheid was. Die enigste uitsonderings is verse $5 \mathrm{c}$ en $13 \mathrm{~b}$ wat latere toevoegings is.

-Wolff (1982) meen dat die hoofstuk nie 'n oorspronklike eenheid is nie, maar 'n latere komposisie. Verse 6, 7b, 8-13a en 14-16 kom van Miga terwyl 3-5, 7a en 13 b deur die Deuteronomistiese redaktor, en vers 2 deur 'n nog latere universalisties-georiënteerde redaktor uit die Persiese tyd bygevoeg is. Volgens Wolff is verse 6-7 en 8-16 retories so eng aan mekaar verbonde (vergelyk die 'daaroor' aan die begin van vers 8 ) dat dié twee dele uit dieselfde tyd afkomstig moet wees: Dit gaan daarom dat wat van Samaria gesê word, as voorbeeld voorgehou word van wat met Juda en Jerusalem sal gebeur. Op grond van die feit dat Samaria nog nie geval het nie, kies Wolff vir 'n datering voor $722 \mathrm{vC}$. Hy voeg by dat verse 8-16 in elk geval praat van gebeure wat nog moet plaasvind en dus nie in $701 \mathrm{vC}$ gedateer hoef te word nie.

- Renaud (1977) sê dat verse 3-7 en 8-16 twee afsonderlike elemente van Miga se profesie verteenwoordig (vers 2 is 'n redaksionele toevoeging). Verse 3-7 (uitgesluit vers 5c) was oorspronklik 'n onafhanklike profesie wat Miga voor 722 
$\mathrm{vC}$ oor Samaria uitgespreek het. Verse 8-16 is nie 'n selfstandige profesie nie, maar is onlosmaaklik aan verse 3-7 verbind, soos blyk uit die 'daaroor' (1: 8) waarmee na die voorafgaande verwys word. Volgens Renaud haal Miga in verse 3-7'n profesie oor Samaria aan wat hy reeds voor $722 \mathrm{vC}$ uitgespreek het. Hy doen dit ter illustrasie van die punt wat hy wil maak: Wat met Jerusalem en omgewing sal gebeur, is 'n verlenging van wat met Samaria gebeur het. Omdat Gat in vers 10 genoem word, en dié stad ná 711 vC nie meer deel van Juda was nie, meen Renaud dat die beste datering van die profesie in sy huidige vorm in die tyd net voor $711 \mathrm{vC}$ is toe Juda ook deur die Assiriërs bedreig is. (Na my mening bring Renaud se siening van veral die funksie wat die profesie oor Samaria in die geheel van die hoofstuk vervul, 'n belangrike nuwe insig na vore wat, soos hieronder sal blyk, ook die basis van my eie opvatting uitmaak.)

Soos reeds te kenne gegee is, stem ek met Van der Woude saam dat verse 2-16 in sy huidige vorm 'n literêre eenheid is. Ek verskil egter van sy opvatting dat dit ook histories 'n oorspronklike eenheid is. Verder meen ek dat sy datering daarvan in 722 vC (so ook Wolff en Rudolph) bevraagteken kan word. Die vraag wat opkom, is of verse 6-7 (waarop Van der Woude sy datering baseer) historiese inligting ('feite') in die sin wat Van der Woude dit interpreteer, wil gee. Dié vraag hou met 'n tweede verband, naamlik watter funksie verse 6-7 in die geheel van hoofstuk 1 speel. Volgens Van der Woude se eie opvatting is dit wat oor Samaria gesê word deel van die aanloop tot die uiteindelike klimaks van die preek (1: 13-16) waar Miga hom op Lagis toespits. Die gedeelte oor Samaria verrig dus 'n ondersteunende funksie binne die geheel van die betoog (in dié sin sê ook Wolff en veral Renaud dat die profesie oor Samaria nie 'n selfstandige funksie vervul nie, maar as voorbeeld voorgehou word om die erns van wat in verse 8-16 voorspel word, te illustreer). Indien dit waar is, en ek meen dat die struktuur van die hoofstuk dit aantoon, moet ' $n$ mens versigtig wees om verse 6-7 nie ' $n$ te deurslaggewende rol in die vasstelling van die datering te laat speel nie. Veel eerder moet verse 13-16 (waarin dit gaan om Lagis, die plek waar die preek na alle waarskynlikheid gelewer is) as die vertrekpunt geneem word op grond waarvan tot 'n bepaalde datering gekom word.

Wat kan nou uit verse 13.16 afgelei word? In vers 13 a word aan die inwoners van Lagis gesê dat hulle die perde voor die strydwaens moet span. Tereg sê Van der Woude dat dit hier gaan om 'n oproep tot stryd teen die naderende vyand en nie om 'n oproep om te vlug nie. Alhoewel 'n bedreiging van Lagis in $722 \mathrm{vC}$ (aldus Van der Woude) teoreties nie uitgesluit is nie, is die tyd net voor $701 \mathrm{vC}$, toe Sanherib teen Juda opgeruk en ook Lagis beset het, die waarskynlikste tyd waarin 'n oproep soos hierdie gemaak sou gewees het (vergelyk Mays). Van der Woude, asook 
Rudolph, Wolff en Renaud, wys dié datering om twee redes af: Verse 6.7 kon nie ná die val van Samaria uitgespreek gewees het nie; vers 10 , waar van Gat gepraat word, kan nie uit $701 \mathrm{vC}$ kom nie omdat Gat na $711 \mathrm{vC}$ nie meer deel van Juda was nie (laasgenoemde rede hou ook verband met die feit dat byvoorbeeld Rudolph en Renaud nie tussen verse 8-12 en 13-16 onderskei nie).

Myns insiens bestaan daar ' $n$ alternatief wat beide probleme oplos. Dit hou verband met die vraag of die hoofstuk verklaar sou kon word as dit, in sy huidige vorm, uit die tyd net voor Sanherib se veldtog van $701 \mathrm{vC}$ kom. Ek meen dat dit wel die geval is. Wat verse 6-7 betref, het ons ' $n$ geval waar Miga 'n profesie aanhaal waarin hyself, by 'n vorige geleentheid (voor $722 / 1$ vC), die val van Samaria voorspel het (vir hierdie nuwe insig moet die krediet aan Renaud gegee word). Miga doen dit, volgens Renaud, om 'n spesifieke rede: Samaria het intussen reeds geval; deur dus sy profesie waarin hy gesê het dat Samaria sal val, net so aan te haal, terwyl Miga se toehoorders bekend is met die feit dat dit intussen reeds gebeur het, verkry dié woorde 'n verdere toekomsperspektief, naamlik om as waarskuwing vir sy toehoorders te dien oor wat die toekoms vir hulle inhou. Ek verskil wel van Renaud in dié sin dat ek die funksie van dié aanhaling op net verse 13-16 (wat oor Lagis handel en die klimaks van die preek vorm) betrek en nie ook op die gedeelte oor Jerusalem (verse 8-12 ) nie. Wat presies die toekoms vir Lagis inhou, word in verse 13-16 uitgespel: Ook hulle staar ondergang in die gesig. So gesien, met ander woorde binne die konteks van die hoofstuk in sy huidige vorm, pas die profesie oor Samaria ook goed in die tyd net voor $701 \mathrm{vC}$ en hoef die hoofstuk dus nie in die tyd voor 722 vC gedateer te word nie. Verse 6-7 hoef dan ook nie, soos Mays, Fritz (1974: 327-328) en Lescow (1972: 54-59) doen, aan 'n latere redaktor toegeskryf te word nie, aangesien daar geen rede bestaan hoekom dit nie oorspronklik deur Miga uitgespreek kon gewees het nie.

Die beginsel waarom dit hier gaan kry 'n mens ook in Kaiser (1981: 19-60) se verklaring van Jesaja 1 . Hy sê dat ons in Jesaja 1 profesieë vind wat uit die tyd ná die verwoesting van Jerusalem kom. Dié hoofstuk (sowel as die hoofstukke wat volg) bevat egter ook (dele van) profesieë wat uit 'n vroeër tyd kom en wat nog sè dat Jerusalem sal val. In die lig daarvan dat Jerusalem egter reeds geval het, verkry sulke profesieë dan, in 'n na-eksiliese konteks, 'n nuwe dimensie naamlik om as waarskuwing te dien teen optrede wat tot verdere oordeel en katastrofe kan lei. Op analogiese wyse wil Miga met die profesie oor Samaria, wat eintlik reeds uitgekom het, 'n waarskuwing rig.

In die geval van verse 8-12, wat oor Jerusalem en omgewing handel, meen ek dat ons met 'n soortgelyke aanhaling te doen het. Op hierdie punt wil ek dus op Renaud se insig voortbou. Die vraag wat hier opkom, is hoekom Miga so gedetail- 
leerd na Jerusalem en omgewing verwys in 'n preek wat hy by Lagis lewer. Of anders gestel: Is dit nie ten minste 'n moontlikheid dat so 'n gedetailleerde profesie oor Jerusalem, ook in Jerusalem gelewer sou gewees het nie? Dit sou beteken dat Miga, soos in die geval van die profesie oor Samaria, in verse 8-12 aansluit by 'n profesie wat hy reeds by 'n vorige geleentheid uitgespreek het. Daar bestaan twee moontlikhede: Hy kon dit oorspronklik uitgespreek het tydens die Assiriese bedreiging van 714-711 vC of, soos verse 13-16, ook tydens die bedreiging van $701 \mathrm{vC}$. Vers 10 werp lig op hierdie probleem. Dáár word 'n woord tot onder andere die stad Gat gerig. Na 711 vC was Gat egter nie meer deel van Juda nie. Dit is dus hoogs waarskynlik dat dié woorde voor $711 \mathrm{vC}$ uitgespreek moes gewees het.

Wat sou Miga se oogmerk met hierdie aanhaling wees? In breë trekke dieselfde as met dié in verse 6-7. By implikasie sê Miga: Reeds ongeveer tien jaar gelede het ek 'n klaaglied oor die komende ondergang van Jerusalem en 'n paar omliggende stede uitgespreek. Van een van die stede, naamlik Gat, het dit reeds waar geword; verder kan julle (die inwoners van Lagis) self sien watter krisis Jerusalem nou in die gesig staar; daarom, slaan ag op dit wat ek nou oor julle gaan sê. Dit is opmerklik dat Miga in verse 8-12 homself nie, soos in die geval van Samaria, letterlik aanhaal nie, maar meer vry, soos veral blyk uit die formulering van verse 8-9 waar hy deur middel van 'daaroor' ( $1: 8)$ en die suffiks van 'haar ramp' (1:9) by verse 6-7 aansluit. In hierdie geval meen ek dus dat Allen, Rudolph en Hillers deels reg is as hulle verse 8-9 as 'n tipe oorgang tussen verse 2-7 en 10-16 sien. Alhoewel dit nie bo alle twyfel bewys kan word nie, is dit myns insiens ten minste warskynlik dat ons in verse 10-12 (wat ' $n$ afgebakende eenheid in die kleine uitmaak) met ' $n$ redelik getroue weergawe van ('n deel van) die oorspronklike profesie te doen het. Dit is interessant dat dit juis dié verse is wat deur Van der Woude as die werklike inhoud van die klaaglied uitgewys word.

Dit is ook opmerklik dat, sou verse 6-7 en 8-12 sulke aanhalings wees, dit in elk geval nie verander aan die tese dat beide gedeeltes in die huidige konteks funksioneer as aanloop tot dit wat oor Lagis in verse 13-16 gesê word nie.

'n Verdere aangeleentheid ondersteun die opvatting dat ons in hoofstuk 1 met hierdie twee aanhalings te doen het. ' $n$ Aantal kommentatore (waaronder Van der Woude) wys daarop dat verse 5b-c na 'n Fremdkörper lyk en skryf dit dan gewoonlik aan die latere redaktor van die boek toe. Myns insiens het ons hier in 'n groot mate die sleutel tot die verstaan van die hoofstuk. Verse $5 b-c$ is wel later bygevoeg, maar deur Miga self tydens die lewering van sy preek net voor $701 \mathrm{vC}$, en nie deur ' $n$ redaktor nie.

As dié twee stiges vir 'n oomblik buite rekening gelaat word, blyk dit dat verse 2-7'n duidelik afgebakende eenheid uitmaak, en kan dit sooa volg geïnterpreteer 
word: In verse 2-4 word al die volke opgeroep om ag te gee op die feit dat Jahwe kom om te oordeel; in vers 5a word hierdie koms van Jahwe direk met die Noordryk (aangedui deur 'Jakob' en 'die huis van Israel') in verband gebring; in verse 6-7 volg dan die inhoud van die oordeel oor die hoofstad Samaria. So gesien, beteken dit dat Miga se eerste aanhaling nie net verse 6-7 beslaan nie, maar waarskynlik verse 2-7 as geheel (met verse 5b-c natuurlik nie deel van die oorspronklike profesie nie). Dat hy dié profesie, in hierdie vorm, oorspronklik in ongeveer die jaar $723 \mathrm{vC}$ uitgespreek het, is goed voorstelbaar. Omdat hy tydens die lewering van die preek (in die tyd net voor $701 \mathrm{vC}$ ) egter geweet het dat hy later in die preek 'n soortgelyke aanhaling ten opsigte van Jerusalem wil gebruik, voeg hy verse $5 \mathrm{~b}$ en $5 \mathrm{c}$ in om op spesifiek die profesieë oor Samaria (1: 6-7) en Jerusalem (1: 8-12) voorit te gryp. Met dié invoeging kry 'Jakob' en 'die huis van Israel' (1: 5a) 'n wyer betekenis en slaan dit op die Godsvolk as geheel, wat ook Lagis insluit. Op soortgelyke wyse verkry verse $2-5$ a (wat in die oorspronklike profesie van verse $2-7$ die aanloop tot spesifiek verse 6-7 gevorm het) ook 'n wyer funksie. Saam met verse $5 b-c$ vorm dit in die huidige konteks die inleiding tot die hele res van die hoofstuk.

Die argumente op grond waarvan beweer word dat verse Sb-c nie van Miga kan kom nie, is nie deurslaggewend nie. Volgens Van der Woude (1976: 32-33) kom dit van die Deuteronomistiese redaktor van die boek, en wel vanweë die volgende redes: Die vraagsinne met hulle kort antwoorde pas nie in by die toon van die gedeelte nie; die terme 'Jakob' en 'die huis van Israel' (1: 5a) word in verse $5 b-c$ in staatsregtelike sin in terme van die Noordryk ('Jakob' = Israel) en die Suidryk ('die huis van Israel' = Juda) geïnterpreteer, wat nie kenmerkend van Miga is nie; Miga gebruik op geen ander plek die naam 'Jakob' in staatsregtelike sin nie; in stryd met die oorspronklike bedoeling van vers $5 \mathrm{a}$, word die algemeen gebruikte terme 'ontrou' en 'sondes' oordragtelik op Samaria en Jerusalem toegepas; die wyse waarop 'die sondes van die huis van Israel' (1: 5a) met 'die kultushoogtes van Juda' (1: 5c) gelykgestel word, is tipies van Deuteronomistiese kringe.

Verse $5 b$-c hoef egter na my mening nie aan die redaktor toegeskryf te word nie. Een van die argumente wat Van der Woude vir sy opvatting aanvoer, is dat 'Jakob' nêrens in Miga (behalwe in vers $5 b$ ) aanwysbaar in 'n staatsregtelike sin gebruik word nie. Die volgende besware kan egter teen dié siening ingebring word:

In vers $5 c$ word na 'n ryk (Juda) en sy hoofstad (Jerusalem) verwys. In verse $5 b$ en $5 c$ het ons egter met absoluut parallelle grammatikale en sintaktiese konstruksies te doen:

Wie is die ontrou, (naamlik) Jakob? Is dit nie Samaria nie?

Wie is die Juda-hoogtes? Is dit nie Jerusalem nie? 
Daarom sou ' $n$ mens in vers $5 b$ dieselfde as in vers $5 c$ verwag. Die stad waarna in vers $5 b$ verwys word, is Samaria, die hoofstad van die Noordryk. Om na die Noordryk te verwys, kan van 'Jakob' of 'Israel' gebruik gemaak word; in hierdie geval word gekies vir 'Jakob'. Oor die feit dat al vier die name staatsregtelik gebruik word, kan daar dus nie juis twyfel bestaan nie (vgl ook Van der Woude).

Die vraag is nou of hierdie staatsregtelike gebruik van veral 'Jakob', téén die outeurskap van Miga getuig of nie. Om dié vraag te beantwoord moet na die teks van Miga 1: 5-12 gekyk word. Daaruit blyk die volgende: In vers 6 word van Samaria gepraat, in vers 9 van Juda en Jerusalem. Dat dit staatsregtelik bedoel is, is duidelik; selfs Van der Woude ontken dit nie. Miga maak dus wel in sy preek van staatsregtelike terme gebruik. Dit is nou verder opmerklik dat in verse $5 b-c$ presies dieselfde drie benaminge in presies dieselfde volgorde gebruik word en, soos hierbo aangetoon, ook in staatsregtelike sin: Samaria in vers 5 b en Juda en Jerusalem in vers 5c. Hieruit volg die afleiding dat, as Miga in verse 6 en 9 in staatsregtelike sin kan praat, dieselfde waar kan wees van verse $5 b$-c; dan hoef die gebruik van dié drie terme, en by implikasie ook die gebruik van 'Jakob' in 'n staatsregtelike sin, nie téén die outeurskap van Miga te getuig nie.

Wat meer is: Van der Woude maak in sy beswaar van 'n argumentum e silentio gebruik. Die feit dat 'Jakob' nêrens anders in 'n staatsregtelike sin deur Miga gebruik word nie, beteken nie dat dit nie hier die geval kan wees nie. Die feit dat Miga in vers $5 a$ in ' $n$ algemene sin van die hele godsvolk praat en in verse $5 b-c$ pertinent na die twee ryke verwys, is ook nie 'n probleem nie. Verse $5 b-c$ verrig nog steeds, al is dit in staatsregtelike sin, die funksie om na die hele volk te verwys. Dat verse Sb-c uit die toon van die gedeelte val, is ook nie 'n bewys dat dit nie van Miga af kom nie. Dit hou eerder daarmee verband dat Miga dit later ingevoeg het in die oorspronklike profesie oor Samaria (1:2-7). Dieselfde geld wat die argument betref dat die algemeenbedoelde 'ontrou' en 'sondes' van vers $5 \mathrm{a}$ in verse $5 \mathrm{~b}-\mathrm{c}$ oordragtelik op Samaria en Jerusalem toegepas word.

Samevattend meen ek dus dat Van der Woude reg is dat ons hier 'n preek het wat Miga in Lagis gelewer het. Dit is egter nie in sy huidige vorm 'n histories oorspronklike eenheid nie, en ook nie in $722 \mathrm{vC}$ gelewer nie, maar wel in $701 \mathrm{vC}$. Hierdie bespreking illustreer dat ' $n$ mens nie uit die feit dat ' $n$ teksgedeelte in sy 'finale vorm' ' $n$ literêre eenheid uitmaak, die afleiding moet maak dat dit noodwendig ook 'n histories oorspronklike eenheid was nie. Dit illustreer ook ' $n$ ander baie belangrike saak: Dele van 'n teks wat om literêre en strukturele redes as latere toevoegings uitgewys kan word, hoef nie noodwendig aan 'n ander persoon (redaktor) toegeskryf te word nie, maar kan ook soms van die outeur self afkomstig wees. 


\section{Literatuurverwysings}

ALLEN, LC 1976. The books of Joel, Obadiah, Jonah and Micah. Grand Rapids: Eerdmans. (NIC.)

FRITZ, V 1974. Das Wort gegen Samaria Mi 1: 2-7. ZAW 86, 316-331.

HILLERS, DR 1984. Micah: A commentary on the book of the prophet Micah. Philadelphia: Fortress. (Hermeneia.)

KAISER, O 1981. Das Buch des Propheten Jesaja: Kapitel 1-12. Göttingen: Vandenhoeck. (ATD 17.)

LESCOW, T 1972. Redaktionsgeschichtliche Analyse von Micha 1-5. ZAW 84, 4685.

MAYS, JL 1976. Micah: A commentary. London: SCM. (OTL)

RENAUD, B 1977. La formation du livre de Micheé: Tradition et actualisation. Paris: Gabalda. (EtB.)

RUDOLPH, W 1975. Micha - Nahum - Habakuk - Zephanja: Mit einer Zeittafel von Alfred Jepsen. Gütersloh: Gerd Mohn. (KAT 13,3.)

STRYDOM, JG 1988. Micah, Anti-Micah and Deutero-Micah: A critical discussion with A S van der Woude. DTh-thesis, University of South Africa.

VAN DER WOUDE, AS 1976. Micha Nijkerk: Callenbach. (POT.)

WOLFF, HW 1982. Dodekapropheton 4: Micha. Neukirchen-Vluyn: Neukirchener. (BKAT.) 